\title{
Students' Writing Anxiety and Its Correlation with Their Writing Performance
}

\author{
Zulfikri B. Rasuan ${ }^{1}$, Lindra Wati ${ }^{2}$ \\ ${ }^{1}$ IAIN Syaikh Abdurrahman Siddik Bangka Belitung. \\ ${ }^{2}$ IAIN Syaikh Abdurrahman Siddik Bangka Belitung
}

Keywords:

Correlation

Students' Writing Anxiety

Writing Performance

\begin{abstract}
The objectives of this study were to find out: (1) the dominant aspect in writing anxiety, (2) the correlation between students' writing anxiety and their writing performance, (3) the differences between male and female students in students' writing anxiety of the twelfth grade students in Pangkalpinang, Bangka Belitung Province. The sample of this study was 80 students The instruments used were writing anxiety questionnaire and a writing test. The results showed that, cognitive was the most dominant aspect. There was a fair significant correlation between students' writing anxiety and writing performance. T-score was $-0,430$ and T-table was 0,283. The result showed that, there was a negative and strong enough correlation between the students' writing anxiety and their writing perfomance. English learning anxiety gave positive influences to the students' writing performance, not necessarily bad result to writing but drove the students to get motivation to be better from others. In addition, the result of writing anxiety showed that the mean score of male students was 100,27 and the females got 102,60 . So, there was a significant difference between male and female students. Thus, the teachers are suggested to increase students' selfconfidence so that students' writing results are maximized.
\end{abstract}

Correspondence:

Zulfikri B. Rasuan

Email: zulfikri12@gmail.com

\section{Introduction}

Many students consider writing as a struggle and hindrance in coming up with a goodtext. They see writing as an obstacle to academic success. They often encounter what is called writing apprehension or writing anxiety (SISON, n.d.) Anxiety is a part of psychological aspect which consist of as: self-evaluation, excessive concern about failure, concern about what other think, anxiety and worry, avoidance of the target language are less errors and excessive studying (Horwitz, Horwitz, \& Cope, 1986). In addition, students generally have the fear of making mistakes so they believe that in writing they will make many mistakes and this will bring them low grades, though there are other students showed no fear about their learning experience in the past (Supiah, 2018) due to some aspects and one of them is their beliefs in language learning that can be positive or negative (Husnayaini, 2019)

According to Kara (Kara, 2013), anxiety is considered as "one of the factors that affect the process of learning". More over, anxiety can be felt to everyone in any different situation. In the scope of learning, anxiety has a great effect. Furthermore, anxiety is an emotion is common, because of that is a part of everyone's life, especially in education settings. It will affect the learning process of students. For example although the teachers has an argument that there are students who have positivity atttudes towards writing, some English teachers state that students are negative attitude towards writing has a negative effect on their writing performance. For example, in some courses, when the teachers ask students to write, students have anxiety will make mistakes and appear bad. Teachers with negative reactions and continue blame students will certainly make students writing anxiety increase and make students writing progress 
decreases. But on the contrary, some teachers with positive feedback can help students to improve their writing performance (Miri \& Joia, 2018). In short, one of the factors influence students writing anxiety is teacher feedback. The teacher who gives the positive feedback can has a positive effect also on their writing performance and otherwise.

Bruning and Horn (Bruning \& Horn, 2000) stated that writing anxiety occurs because of language complexity in general and complexity of writing as a skill in particular. For the language learners, there is a correlation between writing anxiety and writing performance (Negari \& Rezaabadi, 2012). Less is known about writing anxiety levels for second language (L2) students that actually has an important role for students who learn writing in a foreign language in classroom. Students often fear not being able to express themseleve clearly in their writing because it is not their first language and tend to worry about how others will perceive them after reading their writing (Pajares \& Johnson, 1994; Pajares \& Valiante, 2006). In conclusion, beside language complexity in general, complexity of writing as a skill in particular as one of the factors of writing anxiety.

Based on the preliminary observation, the students have problems in writing skill. They found it difficult to write an English text. They did not understand how to write English well. In fact, most of them did not have good performance in writing.

According to one of the English teachers of the school, there were several factors which made it difficult for them in writing. They only focused on the assessment from the teacher. They fear of negative evaluation. So it can affect their writing. And the second is the type of students who don't really care about English. They did the task from the teacher regardless of whether its right or wrong.

Based on the preliminary research to 211 students, the researcher got the data of the students' writing anxiety. The categories percentages of writing anxiety questionnaires from Cheng as follows:

Table 1

The Percentage of Writing Anxiety Questionnaire

\begin{tabular}{|c|c|c|}
\hline No. & Percentage & Category Level \\
\hline 1. & $65 \%-100 \%$ & High Level \\
\hline 2. & $50 \%-64 \%$ & Moderate Level \\
\hline 3. & $0 \%-49 \%$ & Low Level \\
\hline
\end{tabular}

Adopted from Cheng (Cheng, 2004)

Based on the result of preliminary questionnaire, the students writing anxiety can be categorized into three level, from 211 students, there were 51 students included in the high level showed the percentage $65 \%-100 \%$. Then the moderate level, there were 110 showed the percentage 50\%-64\%. Then, for the low level there were 50 students who got the perecntage $0 \%-49 \%$.

\section{Method}

A quantitative approach with a correlational research was employed in this study which was used to find the correlation between students' writing anxiety and their writing performance. A writing test and a questionnaire distribution were conducted to collect the data.

\section{Sample}

In this study, the writers used stratified random sampling. The writer took 80 students for the sample which was divided equally into 40 male students and 40 female students. Thus, the total number of sample was shown in the table below.

Table 2

The Sample of the Study

\begin{tabular}{|c|c|c|c|}
\hline $\begin{array}{c}\text { Population } \\
\text { (The Number from All the } \\
\text { Twelfth Grade) }\end{array}$ & $\begin{array}{c}\text { 40\% of The } \\
\text { Population }\end{array}$ & Male & Female \\
\hline 211 & 80 & 40 & 40 \\
\hline
\end{tabular}




\section{Instruments}

The data were collected data using two instruments namely;

a. Writing Anxiety Questionnaire

The data of students' writing anxiety was obtained by using writing anxiety questionnaire that contained twenty two items. The questionnaire used five alternative Likert Scale. The questionnaire was adapted from Second Language Writing Anxiety Inventory (SLWAI) which had 22 items questionnaire open-ended developed by Cheng about the anxiety student writers experience when writing in English. The questionnaire also contained a demographic section. This is perceived as consisting of three independent components of cognition, physiology, and behavior so it consists of three aspects namely, somatic anxiety as reflected in negative feelings such as tension, cognitive anxiety as reflected in negative expectations, preoccupation with performance, and avoidance behaviour as reflected in avoidance in writing. The reason for selecting this inventory as a measure of writing anxiety was that it has been proved as being highly reliable and valid by means of correlation and factor analysis (Cheng, 2004). The students answered the questionnaires by via online. The government closed all the schools due to the COVID-19 pandemic. Below was the table showing the aspects in writing anxiety questionnaire:

Table 3

Writing Anxiety Questionnaire

\begin{tabular}{|c|l|c|c|}
\hline No. & \multicolumn{1}{|c|}{ Aspect } & Item Number & Total Number \\
\hline 1. & $\begin{array}{l}\text { Cognitive Anxiety } \\
\text { (fear of negative evaluation) }\end{array}$ & $1-8$ & 8 \\
\hline 2. & $\begin{array}{l}\text { Somatic Anxiety } \\
\text { (feeling nervous and tension) }\end{array}$ & $9-15$ & 7 \\
\hline 3. & $\begin{array}{l}\text { Avoidance Behaviour } \\
\text { (avoid writing task) }\end{array}$ & $16-22$ & 7 \\
\hline & Total & & 22 \\
\hline
\end{tabular}

b. Writing PerformanceTest

Writing performance test was designed to find out the students achievement in good writing performance. The writing text used in this research was in the form of essay. The students were asked to write two kinds of text. The first text was application letter and the second one was procedure text. The students wrote the essay based on the topic in the syllabus which consisted of 100 minimum words. The time provided was 90 minutes. The students were doing the writing test by via online also.

\section{Technique for Analyzing the Data}

a. Data Analysis for Questionnaire

1. The Score of Students' Writing Anxiety

The data of students' writing anxiety was analyzed by descriptive in SPSS 22.0 program.

Table 4

The Percentage of Writing Anxiety Questionnaire by Cheng

\begin{tabular}{|c|c|c|}
\hline No. & Percentage & Category Level \\
\hline 1. & $65 \%-100 \%$ & High Level \\
\hline 2. & $50 \%-64 \%$ & Moderate Level \\
\hline 3. & $0 \%-49 \%$ & Low Level \\
\hline
\end{tabular}

The table above explained the criteria of percentage interpretation score by Cheng. It could be seen that if the item score of questionnaires has been obtained, it should be interpreted. From the table above, if the 
score was between in $0 \%-49 \% \%$, it could be in low level. If the score was $50 \%-64 \%$, it could be in moderate level. If the score was in $65 \%-100 \%$, it could be in or high level.

\section{b. Data Analysis for Writing Test}

The researcher gave the students writing test. There was one text and two topics in text which was given to the students. They wrote minimum 100 words each topic. The data is analyzed by SPSS 22.0 program.

In scoring the test, there were two raters (English teachers) to check the result of the students' writing test by giving the score according to the rubric given. Heaton divides the scale of writing composition into five aspects namely content, organization, vocabulary, grammar, and mechanics. Each of the aspect is described in the following rubric (Henning, 1990).

Then, the results between two raters were compared by having the average score of each student. The indicator of writing achievement scores would be presented in the following table.

Table 5

The Indicator of Writing Achievement Scores

\begin{tabular}{|c|c|c|}
\hline Level & Scoring Range & Category \\
\hline A & $86-100$ & Excellent \\
\hline B & $71-85$ & Good \\
\hline C & $56-70$ & Average \\
\hline D & $41-55$ & Poor \\
\hline E & $0-40$ & Failed \\
\hline
\end{tabular}

c. Correlational Analysis

Before calculating the correlation between students' writing anxiety test using Pearson Product Moment formula, the writers tested requirement analysis, namely normality test. Test of normality used the formula of chi-square.

There were two data which was analyzed in this research, students' writing anxiety and students' writing performance. Data related to students writing anxiety was used as variable $\mathrm{x}$ (independent variable), whereas data related to the students' writing performance was used as variable y (dependent variable).

In this research, Pearson Product Moment was used between both variables. In the correlation technique, the variables were compared to know whether or not there was a significant correlation between students' writing anxiety and their writing performance. The function of Pearson Product Moment or correlation analysis was finding the relationship between independent variable (X) and dependent variable (Y) and interval data and ratio.

The result of the t-score was compared to the t-table with significance level $\alpha=5 \%$. The interpretation is if $t_{\text {score }}>t_{\text {table, }}$, so H1 was accepted and it meant that the correlation was significant, and on the contrary.

\section{Validity and Reliability of the Instruments}

a. Validity

This session discussed validity of the instruments. In this study, item validity was used. The try-out to other students in different school with the same level was used. The try-out was tested to 30 students. Afterward, the data was processed by using the Pearson Product Moment formula of SPSS 22.0 with $\mathrm{r}_{\text {table }}$ for $\mathrm{N} 24$ at the level of significance $5 \%$ were 0,404 .

There were two kinds of validity measured in this research; those were validity of questionnaire of students' writing anxiety and writing performance. Based on the result of the validity, it shows that the validity of writing test were two kinds of text, namely application letter and procedure text. The result showed all of topics were valid.

b. Reliability

The second instrument of collecting data is reliability instrument test. The researcher used SPSS 22.0 version of windows to analyze the test. From the calculation, it was found that the result of Cronbach Alpha for questionnaire of students' writing anxiety with significance level 5\% was 0,896 and 0,716 for the writing achievement test. The value of $\mathrm{r}$ table for $\mathrm{N}=26$ is 0,404 . It meant that questionnaire of students' 
writing anxiety was reliable because the result of Cronbach Alpha was higher than $\mathrm{r}_{\text {table }} ; 0,896>0,404$; and writing performance test was reliable too because the result of Cronbach Alpha was higher than $\mathrm{r}_{\text {table }} 0,716$ $>0,404$

\section{Results and Discussions}

1. The Results of Students' Writing Questionnaire (High, Moderate and Low Anxiety)

There were 22 items of the questionnaires and the options of answer used Likert Scale namely $1=$ strongly agree disagree, $2=$ disagree, $3=$ neutral, $4=$ agree, $5=$ strongly agree. The descriptive of data was divided into sample group and per items of questionnaire. The data was analyzed by SPSS 22.0.

a. Destriptive Statistics of Students Writing Anxiety Questionnaire

It was found that the value of mean, the maximum score gined by the student was 32,00 and the minimum score was 15,00 . Then the standard deviation was 3.553 . The following table determined the descriptive analysis of the questionnaire.

Table 6

Mean, Standard Deviation, Maximum, Minimum Score of Students Writing Anxiety Statistics

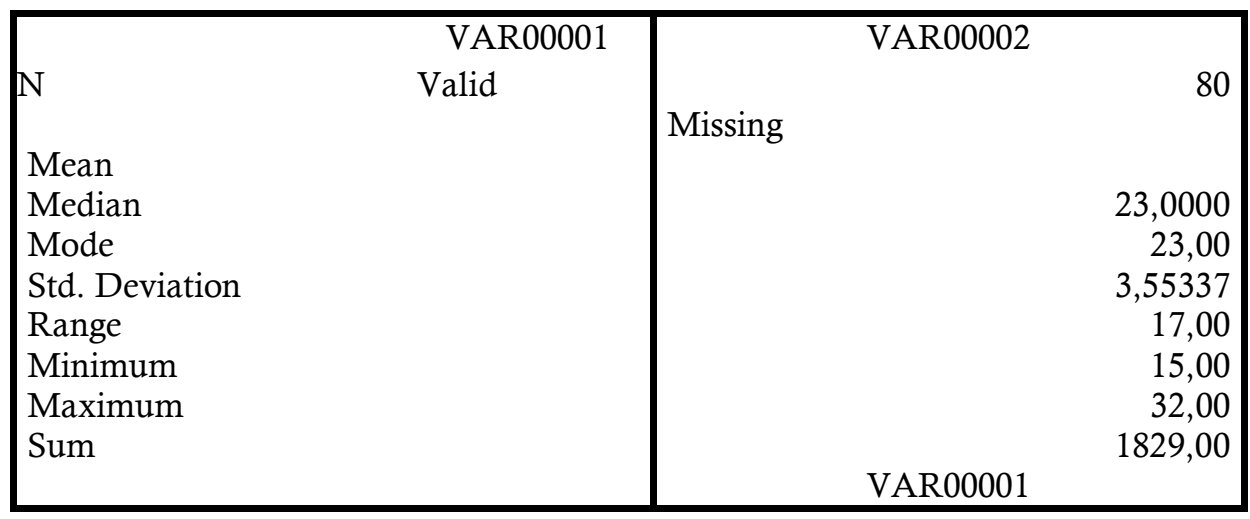

Furthermore, to know the descriptive of students' writing anxiety, the categories percentages of writing anxiety questionnaires from Cheng was used and shown as follows.

Table 7

The Percentage of Writing Anxiety Questionnaire

\begin{tabular}{|c|c|c|}
\hline No. & Percentage & Category Level \\
\hline 1. & $65 \%-100 \%$ & High Level \\
\hline 2. & $50 \%-64 \%$ & Moderate Level \\
\hline 3. & $0 \%-49 \%$ & Low Level \\
\hline
\end{tabular}

Adapted from Cheng,(Cheng, 2004)

The result of the percentage was in the following table.

Table 8

Mean of Variable X (Students Writing Anxiety)

\begin{tabular}{|c|l|c|c|}
\hline No. & \multicolumn{1}{|c|}{ Aspects } & Percentage & Criteria \\
\hline 1 & Cognitive Anxiety & $66 \%$ & High \\
\hline 2 & Somatic Anxiety & $57 \%$ & Moderate \\
\hline 3 & Avoidance Behaviour Anxiety & $30 \%$ & Low \\
\hline & Total Mean & $\mathbf{5 1 \%}$ & Moderate \\
\hline
\end{tabular}


The table above informed that the students' writing anxiety in cognitive anxiety showed the percentage was $66 \%$, so it was categorized as high level criteria. Then, the somatic anxiety showed the percentage was $57 \%$, that was included in moderate level. For the students' avoidance behaviour, showed the percentage was $30 \%$, that was categorized as low level. The total mean of the twenty two items was $51 \%$ and it was in moderate level criteria. Thus it mean that, the students' writing anxiety was moderate level.

b. Descriptive Statistics of Students' Writing Anxiety Questionnaire (Per Items)

The maximum score for the questionaire was 400 if from 80 students answered in scale 5 for one item questionaire, and the minimum score was 80 if from 80 students answered in scale 1 for one item questionaire. It is used to range the level of students' writing anxiety. It consists of 22 items, and there are seven items $(1,3,6,8,16,21,22)$ in SLWAI which are negatively worded and require reverse scoring before being summed up to yield the SLWAI total score. A total score above 65 indicates a high level of writing anxiety; a total score below 50 indicates a high level of writing anxiety, and a total score inbetween indicates a moderate level of writing anxiety.

\section{The Results of Writing Test}

The instruments used to obtain the data of students' writing anxiety were a writing test. The test consisted of descriptive text and were 2 text.

a. Descriptive Statistics of Students Writing Test

In this study, a writing test was used to collect the data. After the writing test was given to the sample, it was found that the highest score was 87 and the lowest one was 42 . Then, the mean score of the data was 60.82 , the range was 45 and standard deviation was 9,173 .

Table 9

Statistic Students' Writing Performance

Statistics

\begin{tabular}{|l|r|}
\hline N $\quad$ Valid & 80 \\
Mean $\quad$ Missing & 0 \\
Std. Error of Mean & 60,8250 \\
Median & 1,02559 \\
Mode & 63,0000 \\
Std. Deviation & 63,00 \\
Variance & 9,17312 \\
Range & 84,146 \\
Minimum & 45,00 \\
Maximum & 42,00 \\
Sum & 87,00 \\
\hline
\end{tabular}

Furthermore, to know description of the result students' writing performance, the researcher used central tendency (mean) which described each of students' writing performance. The scores were divided into five categories: Very Good, Good, Enough, Low, and Very Low as shown in the Table 16 below.

Table 10

The Score Distribution of the Writing Test Results

\begin{tabular}{|c|c|c|c|c|}
\hline No. & Scoring Interval & Category & Frequency & Percentage \\
\hline 1 & $86-100$ & Very Good & 1 & $1,3 \%$ \\
\hline 2 & $71-85$ & Good & 12 & $15,1 \%$ \\
\hline 3 & $56-70$ & Enough & 44 & $55,1 \%$ \\
\hline 4 & $41-55$ & Low & 23 & $28,8 \%$ \\
\hline 5 & $1-40$ & Very Low & 0 & $0 \%$ \\
\hline \multicolumn{3}{|c|}{ Total } & 80 & $100 \%$ \\
\hline
\end{tabular}


As shown in Table 12 above, it was found that there was 1 student $(1,3 \%)$ in very good category, 12 students $(15,1 \%)$ in Good category, 55,1 students (44\%) in enough category, there was 23 students $(28,8 \%)$ in low category, and there was no student $(0 \%)$ of the sample in very low categories.

\section{Statical analysis of the Correlation between Students' Writing Anxiety and Writing Performance}

\section{a. The Correlation between Students' Writing Anxiety and Writing Performance}

The correlation was tested by appliying the formula of correlation coefficient $\left(\mathrm{r}_{\mathrm{xy}}\right)$ Pearson Product Moment between the correlation students' perceptions as predictor variable (X) and writing achievement as criterion variable $(\mathrm{Y})$. The result of calculation was compared with the critical value in a table of significance level $5 \%(0.05)$. If $r_{x y}$ is higher than $r_{\text {table }}$, thecorrelation is significance and if $r_{x y}$ is lower than

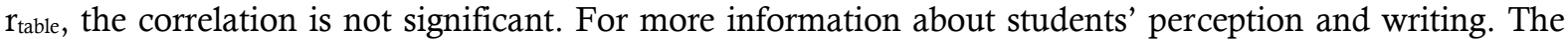
result of correlation coefficient between two variables was presented in the following table.

Table 11

Correlational Analysis between Students' Writing Anxiety (X) and Writing Performance (Y)

\begin{tabular}{|ll|r|r|}
\hline \multicolumn{3}{|c|}{ Correlations } \\
\hline X (Students' & Pearson & X & \multicolumn{1}{|c|}{ Y } \\
Writing & Correlation & 1 &,$-430^{* *}$ \\
Anxiety) & Sig. (2-tailed) & &, 001 \\
& $\mathrm{~N}$ & 80 & 80 \\
\hline Y (Writing & Pearson & $-430^{*}$ & 1 \\
Performance) & Correlation &, 001 & \\
& Sig. (2-tailed) & 80 & 80 \\
\hline & $\mathrm{N}$ & \multicolumn{2}{|c|}{ (2-tailed). }
\end{tabular}

The table above showed the information about the result of correlation coefficient computation was 430 and the critical value in a table at the significant level $1 \%$ was 0.283 . Since $r_{x y}$ was lowerr than $r_{\text {table, }}$, The negative sign means there is negative correction between two variables. The correlation in this research is reversed where an increase in one variable causes a decrease in the value of another variables.

Afterward, the analysis above was known that hypothesis is that there is a significant correlation between students' writing anxiety and writing performance was accepted. Then, the correlation between both variables was also classified into interpretation coefficient correlation value $\mathrm{r}_{\mathrm{xy}}$ categories as stated in table 16. From the result of $r_{x y}=0,430$ was in the interval $0.40-0.599$. It means that the correlation between students' perception on students' writing anxiety and writing performance was in strong enough criteria.

b. The Correlation between Each Aspect of Students' Writing Anxietyand Writing Performance.

The researcher found that there was a correlation between each aspect of students' writing anxiety and writing performance namely, cognitive anxiety, somatic anxiety and avoidance behaviour anxiety. the result were explained as follows.

Table 12

Correlation between Students' Writing Anxiety and Each Aspect of Writing

\begin{tabular}{|c|c|}
\hline Writing Anxiety Aspect & Pearson Correlation $\left(\mathbf{r}_{\mathbf{x y}}\right)$ \\
\hline Cognitive Anxiety & -417 \\
\hline Somatic Anxiety & -294 \\
\hline Avoidance Behaviour Anxiety & -254 \\
\hline
\end{tabular}


Table 14 above shows the correlation between each aspect of students' writing anxiety and writing performance. First, there was a negative fair significant correlation between cognitive anxiety and writing performance. The correlation coefficient Pearson Correlation was -0.417 and the p-value was 0.000 . Then, it was categorized into strong enough correlation because the range of correlation 0.40 to 0.599 was categorized into strong enough correlation. The correlation was significant because the p-value 0.000in Sig. (2-tailed) was lower than 0.01 . The second, there was a weak significant correlation between somatic anxiety and writing performance. The correlation coefficient Pearson Correlation was -0.294 and the pvalue was 0.000 . Then, it was categorized into was categorized into weak correlation because the range 0.20-0.399 was into weak correlation. The correlation was weak significant because the p-value 0.000in Sig. (2-tailed) was lower than 0.001 . The third, there was a weak significant correlation between av and writing idance behaviour anxiety and writing performance. The correlation coefficient Pearson Correlation was -0.254 and the $p$-value was 0.000 . Then, it was categorized into was categorized into weak correlation because the range $0.20-0.399$ was into weak correlation. The correlation was weak significant because the p-value 0.000in Sig. (2-tailed) was lower than 0.001

c. Statical Analysis of Male and Female Students in Students' Writing Anxiety

1. The Differences Between Male and Female Students in Students' Writing Anxiety

Before finding the differences between male and female students in their writing anxiety, the following table shows the comparing score between the two.

Table 13

Comparison Score between Male and Female in Students' Writing Anxiety

\begin{tabular}{|c|l|c|c|}
\hline No. & \multicolumn{1}{|c|}{ Aspect } & Male(40) & Female(40) \\
\hline 1. & Mean & 100.27 & 102.60 \\
\hline 2. & Maximum & 122 & 116 \\
\hline 3. & Minimum & 74 & 81 \\
\hline 4. & Sum & 3008 & 4309 \\
\hline
\end{tabular}

The table showed the number of male students was 40 and the female students was 40 as well. The minimum score for male student was 45 , the maximum was 81 , and their mean 61,2570 . The minimum score for female student was 47 , the maximum score was 77 , and their mean was 61,350 . From the result above, the female students' mean was higher than male students in students' writing anxiety symbolized $102.60>100.27$. It means that the female students can be said were easy to get the knowledge of English language subject.

To know whether or not there is any differences between male and female students in students' writing anxiety is by looking the p-value in colom of t-test for Equality of means with significance level 0.05 .

\section{Conclusions}

Based on the result of findings, cognitive anxiety becomes the dominant aspect of writing anxiety experienced by the students. The percentage score of cognitive anxiety was $66 \%$. The next aspect of writing anxiety is somatic anxiety with the percentage $57 \%$, and the last aspect of writing anxiety is avoidance behaviour with the percentage $30 \%$. It was found that, in general the students' writing anxiety was in moderate level with the percentage $55 \%$ by 44 students, the students' writing anxiety was in high level with the percentage $25 \%$ by 24 students and the students' writing anxiety was in low level with the percentage $20 \%$ by 16 students. Meanwhile, from the analysis of using pearson product moment, it was found that students' writing anxiety and writing performance were correlated because the coefficient correlation between both variables $\left(\mathrm{r}_{\mathrm{xy}}\right)$ was 0.430 .

From the results of the study, it could be implied that, the students faced cognitive anxiety feel worried when they think that their English compositions are a lot worse than others' and they feel anxious when their composition will get a poor score if it is evaluated. They are afraid of getting a negative evaluation. It is also caused by writing anxiety factors such as, lack of writing practice in a foreign language, not enough mastery of writing technique, and lack of knowledge on topics that discussed. In addition, having lots of 
linguistic problems (grammar, diction, and vocabulary), the pressure to work on foreign language essays perfectly, time pressure, lack of confidence are also the factors which contribute to students writing anxiety.

Beside three aspect of writing anxiety, there are also ecternal factors supporting the result of writing text, such as claasroom activities, classroom management, teacers strategy, teachers approach and sociocultural factors (Kitao \& Kitao, 2013). Internal factors can also be known as the personality factors supporting the result of writing text there are self esteem, inhibition, risk taking and motivation (Puspita, 2019).

The relationship between students' writing anxiety and writing performance were negative and strong enough correlation. The result of correlation coefficient computation was -430 and the critical value in a

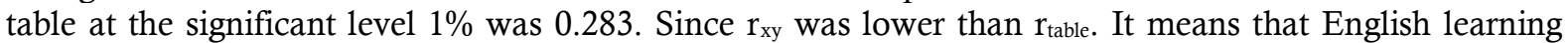
anxiety gave positive influences for the students' writing performance. English learning anxiety drived the students to give better performance because the students got motivation to be better from others. The students with the high anxiety were not always categorized as the bad students, but some of them were good with academic track record. The students felt anxious because they got experience from their friends that were not easy to achieve good scores from the class. However, some students with the low anxious and achieved low scores. It happened because they were not serious in following the subject, ignoring to write the subject, feeling lazy to study the subject. In fact, in writing class, the students are expected to more practice, add vocabulary, be careful with writing systems, and have good logic in expressing the ideas.

The result of the correlation each aspect in writing anxiety and writing performance which cognitive anxiety had the stroung enough correlation. The correlation coefficient Pearson Correlation was -0.417 and the p-value was 0.000 . The correlation between writing performance and each aspect of writing had the strong significant correlation between students' writing anxiety and language use on students' writing. The correlation coefficient Pearson Correlation was 0.659 and the p-value was 0.000 . And the weak significant correlation between students' writing anxiety and mechanics on students' writing. The correlation coefficient Pearson Correlation was 0.231 and the p-value was 0.000 It means that, eventhough weak significant correlation.

After getting the result of the study, the result was compared with the previous studies. The result of this research was same with research conducted by Kurniasih (Kurniasih, 2017) and Margareta (Arindra $\&$ Ardi, 2020). The result was there was a fair negative correlation between students writing anxiety and writing performance (Puspita, 2019). So it could be concluded that there is correlation between writing anxiety and writing perfomance but different on the level high or low correlation.

From the findings of the study, it could be implied that, the teachers of English should know the level of students' writing anxiety and which dominant aspect in writing anxiety. The teaching strategies should be considered as a significant part of teaching process to reduce students' writing anxiety and could improve the students' writing performance.

The last is to find the differences between male and female students in writing anxiety. From the calculation, female student achived score in writing anxiety higher than male students. The difference was significant because the p-value was lower than the significant level 5\%. So, it could be implied that there was a significant difference between male and female students in writing anxiety. Female students have significantly higher anxiety levels than males in terms of writing English compositions. It means that, male students do not care much about others' perception of their writing performance. On the other hand, female respondents tend to be worried that their English composition is worse than others. It means that, female students are more likely to worry about others' perception of their writing performance. The reasons show that both males and females faced anxiety due to a lack of linguistic ability. The study implied that, teachers should be aware of the factors affecting the anxiety experienced by male and female students when they are learning to write in English.

\section{References}

Arindra, M. Y., \& Ardi, P. (2020). The correlation between students' writing anxiety and the use of writing assessment rubrics. LEARN Journal: Language Education and Acquisition Research Network, 13(1), 76-93.

Bruning, R., \& Horn, C. (2000). Developing motivation to write. Educational Psychologist, 35(1), $25-37$. 
Cheng, Y.-S. (2004). A measure of second language writing anxiety: Scale development and preliminary validation. Journal of Second Language Writing, 13(4), 313-335.

Henning, G. (1990). Writing English language test: Heaton, JB London and New York: Longman, 1988, 192 pp., 6.50 (Longman Handbooks for Language Teachers). System, 18(1), 114-115.

Horwitz, E. K., Horwitz, M. B., \& Cope, J. (1986). Foreign language classroom anxiety. The Modern Language Journal, 70(2), 125-132.

Husnayaini, I. (2019). Language Learning Beliefs of High School Students In Bangka Belitung. Scientia: Jurnal Hasil Penelitian, 4(2), 205-224.

Kara, S. (2013). Writing anxiety: A case study on students' reasons for anxiety in writing classes. Anadolu Journal of Educational Sciences International, 3(1), 103-111.

Kitao, K., \& Kitao, S. K. (2013). Selecting and Developing Teaching/Learning Materials. The Internet TESL Journal, IV (4). Avalable at Http://Iteslj. Org/Articles/Kitao-Materials. Html. Accessed, 2.

Kurniasih, K. (2017). Writing Anxiety in Relation to High Performing Studentsâ ${ }^{\mathrm{TM}}$ English Compositions. BRIGHT: A Journal of English Language Teaching, Linguistics and Literature, 1(1).

Miri, M. A., \& Joia, J. (2018). Writing anxiety in an Afghan EFL setting: Voices from five Afghan students. Journal of Foreign Language Teaching and Learning, 3(1), 14-29.

Negari, G. M., \& Rezaabadi, O. T. (2012). Too nervous to write? The relationship between anxiety and EFL writing. Theory and Practice in Language Studies, 2(12), 2578.

Pajares, F., \& Johnson, M. J. (1994). Confidence and competence in writing: The role of self-efficacy, outcome expectancy, and apprehension. Research in the Teaching of English, 313-331.

Pajares, F., \& Valiante, G. (2006). Self-efficacy beliefs and motivation in writing development. Handbook of Writing Research, 158-170.

Puspita, C. (2019). FACTORS AFFECTING STUDENTS'DIFFICULTIES IN WRITING THESIS: A MIXED-METHODS RESEARCH AT EIGHTH SEMESTER OF ENGLISH STUDY PROGRAM IN IAIN CURUP. English Language and Literature International Conference (ELLiC) Proceedings, 3, 13-22.

SISON, S. J. G. (n.d.). DISCERNING THE RELATIONSHIP OF WRITING APPREHENSION LEVEL AND LANGUAGE ATTITUDE OF FEMALE AND MALE STUDENTS IN A STATE UNIVERSITY.

Supiah, S. (2018). The Attitude Of Non-English Major Student In Learning English. Tarbawy: Jurnal Pendidikan Islam, 5(1), 41-47. 